\title{
6: 114398967-114368621
}

National Cancer Institute

\section{Source}

National Cancer Institute. 6:114398967-114368621. NCI Thesaurus. Code C42457.

Physical location of HDAC2_Gene 